\title{
Description the Problems between Fathers and Children in the Batyrlar Zhyry (Kazakh Heroic Epic) and Lyrical Epic
}

\author{
Rita Sultangalieva \\ The Associated Professor and Candidate of Philology of the West Kazakhstan State University Named \\ M. Otemisov, Oral sity, Kazakhstan
}

\section{Doi:10.5901/mjss.2015.v6n5s1p295}

\section{Abstract}

Article is based on description the problems between fathers and children in the batyrlar zhyry (Kazakh heroic epic) and lyrical epic which is related to the Kazakh oral literature. It's about the relationship between fathers and children in the batyrlar zhyry (Kazakh heroic epic) and lyrical epic which is described by the rules of home, social and temper psychologies. It is not only about the relationship between fathers and children of one family, it is about the social problems on a global scale.

Keywords: folklore, epos, lyrical epic, motive, plot, problem, conflict, spiritual and esthetic necessity, continuation of culture, teris bata (damn).

\section{Introduction}

Folklore and poetical continuation in literature in the history of Kazakh verbal skills are known as a main thing of the literary developing. Psychological and poetical objective reality of the relationship between fathers and children related to the source of literature. Fictions have the main point of peoples opinions about the environment and families who had the everyday problems of living and their influence on it. This article is about the fathers and mothers who struggle with many faced problems saving their children and it has the description of their holding responsible for them. Furthermore it is about the motives of the relationship between fathers and children which occur rarely. We made an analysis and drew a conclusion by the fragments of verses about the situations as people who sacrificed their children's happy in order to save their wealth and their hopelessly sacrificing their children and fast horses' lives in order to stand by their words and about the teris bata (damn).

\section{Problems between Fathers and Children}

Whatever we read in literature, all the stories from the real life. We have to keep in mind that the main thing in verbal skill is the person. However we know that person has different character in different situation. So, we now tell about the description of the relationship between fathers and children which is related to the batyrlar zhyry (Kazakh heroic epic) of the oral literature. We see that this problem has two different descriptions as well in batyrlar zhyry (Kazakh heroic epic). The first one is traditional description. It is about the parents and their responsibility for their children. They bless and pray for them before their hitting the road. They are even ready to sacrifice their own lives for their children. Sixty years old Analyk and ninety years old Toktarbai's asking God to give them a child in the zhyr "story" is the example for it. When the army leaded by Karaman was going to capture Kyrly sity, sister and parents wished like that:

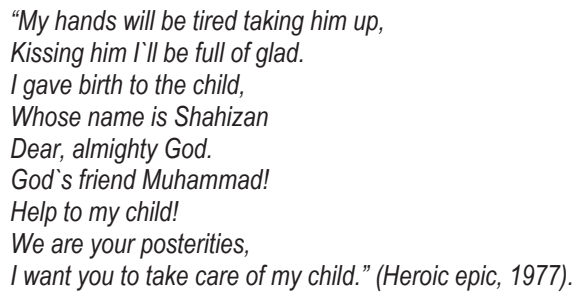

We can see here that mother Analyk and father Toktarbai were really close and dear to their only child. We also 
notice here that they prayed for him. They wanted their son to be safe and achieve a goal.

Moreover, we have to read sister Karlygash`s words to her brother while they were saying goodbye to each other:
"Listen to me my brother,
Until you come from this journey,
Until people see your being all right,
I want you,
The king of the eighteen thousand worlds
To safe my brother...(Heroic epic, 1977).

Young man being blessed and wished by his parents and sister took the road to war.

It is also normal, if the brave man has a gentle disposition. After his sister and mother's exciting parting words, the strong man`s eyes filled with tears. Thinking about his parents health the young man`s feeling described in the verse like that:

"Stop, mother, don't cry,

Crying doesn't solve the problem

Until I come back

I want you, God to safe

My parents and my people." (Heroic epic, 1977).

We can see here that the relationship between parents and child has a real feeling. And we also notice here that it has traditional description. While their child was far away, his parents endured suffering and they had a tough life. It also helps to touch the ground in our research. While their child was far away, parents missed him and needed his taking care of them. Who knows, if he were with his parents, Alashagyr wouldn`t humiliate them. So, this situation takes place in the next verse:

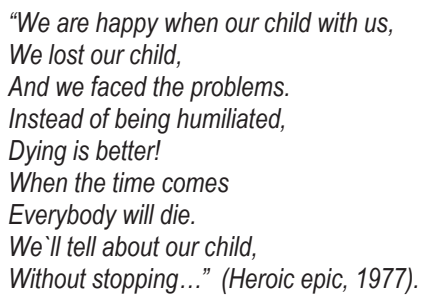

However, despite suffering, they didn't lose their hope about their son. That is why they believed that their son would come back safely and liberate them from sufferings. They believed that he would live up to their expectations.

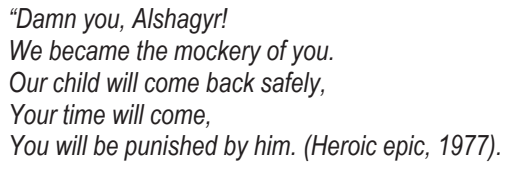

So, giving like these fragments, we can notice the problem between father and son and how it was described in the batyrlar zhyry (Kazakh heroic epic) as "Kobylandy batyr" (Brave man Kobylandy). As we before mentioned, we can see here about parents and responsibility of the child and really close to each other people. We can also notice the impressive descriptions about the merciful people who worry about their son and pray for him and the description of the benevolent parents.

In most stories, the brave man's advisor is clever and well-mannered. Estemis (called Bek in some variants) who looks after horses in "Kobylandy batyr" (Brave man Kobylandy) is described as a close friend of the young brave man. Before going to Kurtka`s country, Kobylandy asked him to bless him:

"Bless me, my brother"

He persuade him" - says like that in the story. 
Brave men respected devoted to them older people saying "brother" and "older sister" and they worked for their masters with pleasure as well.

They liberated waiting for a child older people, when they had a long-expected child. (The history of Kazakh literature, 1960).

Whatever happened, they believed that having a child were the best gladness and happiness for all parents in the world. We can see here having social status of every day`s events and relationship between each other.

Brave man could do his justice despite where he was brought up and parents social position. King was fair. Rich, brave, well-meaning, poor people and workers were harmless. Sometimes if brave man's father is a rich man, it is a weak point. The brave man's king and rich father does not show an interest in people`s problem. They worry about the child just because who will inherit their wealth.

Furthermore, considering this problem on a global scale, we can also give a heroic epic "Alpamys batyr" (Brave man Alpamys) and how this problem was described.

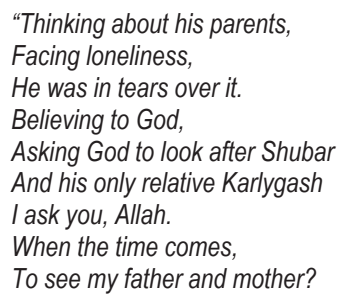

These fragments were described by the traditionally way. We can also notice here the main point of our research as the benevolence of the parents and child to each other. It is the relationship between Alpamys and his parents. However, if we read the first episode, we have to emphasize the relationship between Sarybai and Gulbarshyn. Sarybai also thought about his daughter's future. Alpamys was only one. Everybody knew what would happen to his daughter who belonged to the slave, if he would die. We can see it from these fragments:

"I'll not give my only daughter,

She'll not give birth then.

Great brave man Alpamys will die,

He can not help us then.

After Alpamys's death,

She will marry slave.

After marrying the slave,

What humiliations she will see,

Thinking about it Sarybai,

He is always having a bad mood..." (Heroic epic, 1977).

He didn`t take his daughter from her future husband and he didn`t make her unhappy. We can only understand him as a father who was worrying about his daughter.

And now we'll tell about Alpamys`s parents suffering and profound sorrow, when he was away. We can notice that Alpamys and his parents had close relationship and meeting each other they had deep, innermost feelings. It is the psychological exciting moments.

\footnotetext{
"Seeing his mother Alpamys,

He broke into tears.

As if she suckled him,

His eyes twinkled.

He dismounted from his horse then,

He was really brave man.

Saying "Your only child has come, mother".

The mother hugged him,

Mother and child,

Crying met each other.

And the other ones say:

"Baibori fell down to the stone,
} 
He shed a tear.

As if father and son

Lost their way in the steppe

And they met each other". (Heroic epic, 1977).

By studying these fragments of the verses, we are convinced that our researching problem as the relationship between fathers and children is described by the traditionally way.

We know that heroic epic "Alpamys batyr" (Brave man Alpamys) has several variants. It is a rare event -one of the variants of the heroic epic "Alpamys batyr" (Brave man Alpamys) which was published in 1961, Kalmak's brave man Karazhan fell in love with Gulbarshyn and he started to fight with his own king. He suffered a defeat in duel with Alpamys. He understood then that he was not an invader, he was a real brave man who was looking for his wife and they became friends. Our researching problem is described by the unexpectedly way as a friendship between Alpamys and Kalmak's brave man Karazhan. Brave man Karazhan's son was leading in horse race. He wanted his friend`s horse to lead and get Gulbarshyn. He killed his favorite fast horse for the sake of friendship. It is a little bit different situation. However, showing proof of my words, I give a described fragment of this event:

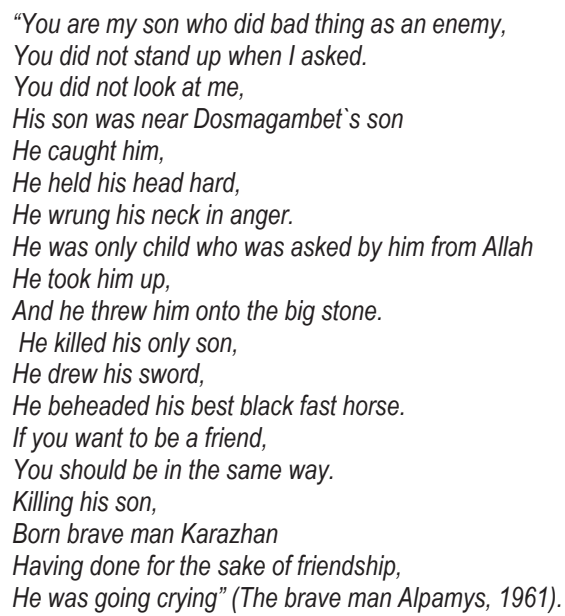

It does not mean here that father hates his son. It is because of the disobedience of him. It proves that brave man was ready to sacrifice everything in order to promote friendship. That is why it does not count as a brutality. On the one hand he sacrificed his son and his fast horse's life for friendship and on the other hand we can see how he was going crying.

We have learned here that the relationship between fathers and children in the batyrlar zhyry (Kazakh heroic epic) was described by the traditionally way. It is about the parents and responsibility for a child. They blessed him before taking the road and prayed for him. They were ready to sacrifice themselves for their child. It took place in the relationship between Kobylandy and Toktarbai, Analyk, Alpamys and Baibori, Sarybai and Gulbarshyn.

The relationship between fathers and children are not described only by the traditionally way. One of the variants of heroic epic "Alpamys batyr" (Brave man Alpamys) the events was described in a different way. The described motives in the epic are friendship of brave men and their standing by their words. Our researching problem was described in a different way by the friendship between Alpamys and Kalmak's brave man Karazhan. Brave man Karazhan sacrificed his son's life for the sake of friendship. In this case we can not say that he was described as a cruel person. He also suffered for his son's death and he was going crying. The relationship between two generations is not described only by the traditionally way, it was described by the variety situations in the heroic epics.

\section{The Relationship between Fathers and Children in the Lyrical Epic}

We need keep in mind that person is the second main object of the verbal skill. However we told before that person shows different characters in a different situations. So, continuing our theme we will tell now about the description of the relationship between fathers and children by the other variants of the oral literature as the lyrical epics. 
Our researching problem is the global one. It is true that society exists with people. People have communication and relationship between each other all the time. However, the relationship between fathers and children is described differently in different times. And during that times way of living is also described differently in literature. And now we will tell about this problem which takes place in the lyrical epic. One of the best lyrical epics of Kazakh oral literature is "Kozy Korpesh-Bayan sulu".

Problematical situation between father and daughter was described by the people as Karabai and Bayan in the lyrical epic. In the history of Kazakh literature Karabai is usually described like that: "Merciless, without humanity qualities. He can not appreciate people. Moreover, he is cruel and strict to his own daughter." (Textual researches.., 1983)

"My colts have died, okay Kodar,

Find me some water, Kodar.

If you save my cattle from desert,

I'll give you Bayan, Kodar, -he said.

He promised Kodar that he would give him his daughter if he would save his cattle from desert. He caused young girl to be unhappy.

By these fragments it has been proved that fathers were strict and mothers were well-wishing with children in the Kazakh villages. It is known that this epic has several variants. In most ones Bayan's mother's name is not called. In Shozhe`s variant's interesting thing, Bayan and Kodar's mothers have names as they have active roles in the story.

Bayan 's mother is Karakoz. She was against to Karabai's moving and his failing to keep his word. After some time she met Kozy with pleasure looking for Bayan. Despite everything she dreamed them to be together (Sh. Ybyraiev, 1993).

We see here that the relationship between Bayan and her parents is described in different ways.

And the relationship between Kozy and his parents is perfectly different. We know that his father was died in his childhood and his mother brought him up by herself. And now we will tell about the relationship between Kozy and his mother. In most variants his mother's name is not called. But, in Shozhe's variant her name is known as Mambike.

Mambike worried about her only son. She always wanted to save his life got into trouble. "You should not go to your fiancée", -she said giving advice like that. She was not against to proposed to each other two young peoples ' being together. But, she was afraid of Karabai. She was afraid of losing her dear son. She also warned him that she would get into trouble.

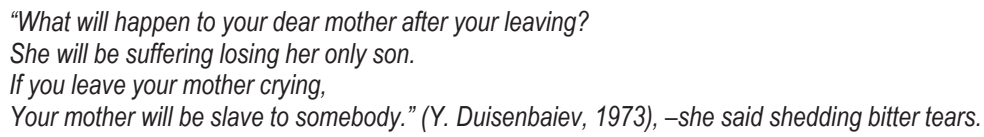

In Berezin's variant esteemed mother does not want her dear son to hit the road. And she did many things in order to his staying in the country. First of all, his mother thought about Kozy would face problems and she wanted him to fear: "What will you do to my poignant tears? You will face the formidable obstacle. You will have the high mountains in your way and you will have the desert steppe which will take forty days to overpass it" -she warned. Finally, she understood that she could not stop her son from this way. Then she started to look for another way to stop him. She told him about his duty to his country:

\section{"You have herd of horses,}

Whom will you leave them to?" [6, p. 60], -she asked like that. However, it could not stop Kodar too. He did not abandon his position. We can also see this situation from the variant of IIminsky (1860). The dialog between the mother and son was described greatly.

"Hey, my son, stay in the country, you will face difficulties, You will go, but Sarybai will not give you his daughter for it. If the child go without listening to his mother,

He will be in trouble and he can not come back home (Y. Duisenbaiev, 1973), -she said.

Besides that Kozy had a dream. In his dream his died father did not want Kozy to go and took a beautiful girl home. However Kozy did not pay attention to her. Kozy was blessed by his father in this dream. 
Kazakh people always bless their children and pray for them before their taking the road. It is the main quality of the tradition of Kazakh people. We can see that the relationship between father and son was described by the traditionally way. As we know the relationship between people is different in society. It is also very different in the epics. It is a natural thing. Parents and child's views were the same as we before mentioned. And the son took the road being blessed by his father. However it does not happen all the time. Sometimes fathers do not agree with their sons' decision. Then because of the misunderstanding, fathers and sons have serious problems between each other. So, in this case fathers damn his sons. We can give the famous lyrical epic "Kyz Zhibek" (Girl Zhibek) as an example for it. We will tell now about the relationship between father and son before teris bata (damn) and how it happened.

In the story of the epic the rich man had a son from concubine in his eighty. He was named Tolegen. After nine years his concubine gave birth to the second son. It was Sansyzbai. Bazarbai was ready to give Tolegen`s bridewealth who was in an agony of suspense. "If he is all right, he will marry to somebody he prefers", -he decided (Y. Duisenbaiev, 1973).

After coming back home, Tolegen was met by his parents with pleasure. They made a feast and they started to ask about everything. After that father and son argued with each other. Bazarbai did not give Tolegen permission to go to his fiancée's country in summer. He forbad everybody to follow him. Tolegen hit the road for reasons of necessity then. In the second part of the epic the story changes completely. Young Sansyzbai missed his being lost brother and started to think how to look for him. He was blessed by his father Bazarbai, took the poet Shege with him and headed for Zaiyk.

First time Bazarbai had a difficult time and he was looked as a nervous person. After some time Tolegen, then Sansyzbai were born and he became a father who was thinking about his childrens' futures. However as we have learned, he was not the same all the time. He was against without any reasons when Tolegen wanted to go to his fiancée`s country second time. He refused to bless him. We can see it from Tolegen`s words:

Saying that I did not listen to him,

My father did not bless me. (Y. Duisenbaiev, 1973), - he said.

Tolegen`s obstacle was his going to Ak Zhaiyk without his old father`s permission. As we know having been damned by father was the big obstacle before. As the author thinks, for all that: "Actually Tolegen is the only lonely one. He was not even supported by his own family. Nobody supported him from all over the world. Nobody gave attention to him. (Y. Duisenbaiev, 1973).

As the narrator concluded, Tolegen certainly had to get into trouble as he did not listen to his father and contradicted him. And Sansyzbai who was blessed by his father had to overcome the difficulties and achieve a goal. (the variant of Zhusipbek kozha Shaihslam)

"It seems the narrator wanted to say that Tolegen died directly because of going without being blessed. The main idea came from the word of wisdom of people as "Father's damning is a bullet". He believed because that it is not right to take the road without being blessed." (Y. Duisenbaiev, 1973).

We can also say that the father did not know that his son would get into trouble then. However teris bata (damn) rare occurs in our Kazakh peoples' lives. But we can not say it does not happen. It is not a shortcoming at all. On the contrary, we can say that it is the quality of the oral literature.

As the centuries pass, people change too and it is a true thing. Our talking the relationship between fathers and children also give diffrent forms because of the regularly changing society. According to it, we have to give the lyrical epic "Aiman-Sholpan" as an example which shows the struggle between old and new traditions. This problem took place in the previous oral literature is occurred in this lyrical epic in a different form. And here not father, child`s view more important. The child is the new generation because. When they wanted to take his daughter, the father could not to protect her. He could do nothing. However Aiman due to her rationality and resourcefulness overcame the difficulties. As if the old tradition had changed.

The description of Aiman is given like that: "The girls usually who are from the family where parents do not have a son dress differently, work about the house and they do not want their parents feel that they do not have a son. They are kind, bright and provident. One of them is Aiman (N. Nabiolla, 2010).

She knew that she could not be to her father as a son. Aiman felt her father's weak point. From the beginning of the quarrelling she understood that they would get into trouble and she beforehand started to hide one part of the cattle. Aiman started to live normally a little bit in the epic. She thought about her old father who was living crying in the country. And the description of the situation was also given as she tried to send Sholpan to the village (M. Awezov, 1991).

So, we can see here that the new generation won and the child’s kindness who started to think about her father. 


\section{Conclusion}

The problem between father and children is seen differently in different society. During that time's way of life is described by different way in literature too. We have learned that our researching the relationship between fathers and children in the batyrlar zhyry (Kazakh heroic epic) is described by the traditionally description way. It is about the parents and their responsibility for a child. They bless their children before taking the road and pray for them. They are always ready to sacrifice their lives for them. It is seen in the relationship between Kobylandy and Toktarbai, Analyk, Alpamys and Baibori and Sarybai and Gulbarshyn (M. Gabdullin, 1974).

The relationship between fathers and children in the batyrlar zhyry (Kazakh heroic epic) is not only described by the traditionally description way. As we before mentioned the situation in one of the variants of "Alpamys batyr" "The brave man Alpamys" is described in a different way. The motives described in the epics are the friendship between brave men and their standing by their words (S. Sadyrbayev, 1977). Our talking problem is described by the unexpectedly way in the friendship between Almapys and Kalmak`s brave man Karazhan. Brave man Karazhan sacrificed his son`s life for the sake of friendship. That is why it does not count as a brutality of the father. He was also suffering because of his son's death and we can see how he was going crying.

This problem was described in the lyrical epics differently. The relationship between Bayan and her father had some problem in the epic "Kozy korpesh-Bayan sulu" (S. Sadyrbayev, 1976). However, the relationship between the mother and her daughter was described by the traditionally description way. The mother was described as a well-wishing and kind person. The relationship between Kozy and his mother was described by the traditionally description way in this epic. His mother was described as a person who was always thinking about her only son and she was looking for the way how to save her son's life from the trouble. She always gave him advice and blessed him. As the relationship between people with each other is seen differently in society, the relationship between people is also different in the epic (The history.., 1988). It is an unchangeable thing of the life. There were also some problems in the relationship between fathers and sons as the fathers did not agree with their sons' decisions. According to it, we can notice here this problem 's feature that Tolegen was damned by his father in the epic. However Kazakh people rare have "teris bata" (damn). We can not also say that it did not happen. It is not a shortcoming of the oral literature. On the contrary, it is the own peculiarity of Kazakh folklore (The history.., 1988). Aiman was not only well-wisher and responsible for her parents in the epic "Aiman-Sholpan", she was the leader of the new generation. The relationship between the old and the younger generations were described in the epic. The old generation's view was old. They did not give attention to the changing world. They wanted to solve the problems as they before did. Aiman and Arystan were the generations of the new epoch. Their opinions are different from the old generation`s opinions. They worry not only about their futures, they think about all peoples ' unity. Their purpose was solving the problem by considering it thoroughly, not only by force. They knew well that the epoch of the quarreling, invading and using force had passed. As the world is changing constantly the relationship between fathers and children in the epics is always different.

\section{References}

Batyrlar zhyry (Heroic epic), (1977). Ak sauyt. T: 1. Almaty. p. 286, 47, 51, 103, 104

The history of Kazakh literature. (1960), T: 1. Folklore. Almaty. Gylym (Science). p. 216.

The heroic epic "Alpamys batyr" (The brave man Alpamys). (1961), Almaty. p. 510-512

Textual researches of Kazakh folklore and literary works. (1983), Almaty. 1, Academy of Sciences. p. 151

Sh. Ybyraiev. (1993), The world of epos Almaty. Gylym (Science).

Y. Duisenbaiev. (1973), Lyrical epic of Kazakh. - Almaty. 2-6, Academy of Sciences. p.67, 91, 97, 318

N. Nabiolla. (2010), In the book: The idea about the Independence and elegant culture. Book I. -Almaty. // The problems about the selfsufficiency and freedom of people. "Kyz Zhibek" (Girl Zhibek). p.113

M. Awezov. (1991). The history of literature. - Almaty. p. 97

M. Gabdullin. (1974). Folklore of Kazakh.- Almaty. p. 118

S. Sadyrbayev. (1977). Folklore of Kazakh people.- Almaty. p. 125

S. Sadyrbayev. (1976). Folklore and esthetic. . - Almaty. p. 76

The history of Kazakh folklore. (1988). - Almaty. p. 45

The history of Kazakh folklore. (1993). - Almaty. p. 88 


\title{
The Intellectuality of Al-Dihlawi: A Review on His Contribution in Science of Prophetic Tradition
}

\author{
Mohd Arif Nazri ${ }^{1}$ \\ Lutpi Mustafa1 \\ Fadlan Mohd Othman ${ }^{1}$ \\ Ahamad Asmadi Sakat ${ }^{1}$ \\ Abur Hamdi Usman ${ }^{2}$ \\ Mohd Fauzi Mohd Amin ${ }^{3}$ \\ 1 Faculty of Islamic Studies, The National University of Malaysia, Malaysia \\ 2 International Islamic University College Selangor (KUIS), Malaysia \\ Corresponding Author Email: aburhamdi@kuis.edu.my \\ ${ }^{3}$ Faculty of Quranic and Sunnah Studies, Islamic Science University of Malaysia, Malaysia
}

Doi:10.5901/mjss.2015.v6n5s1p302

\begin{abstract}
The greatest scholar of 18th century India better known as Shah Wali Allah al-Dihlawi who wrote a number of works, especially on the science of prophetic tradition (hadith). He was a scholar who contributed many ideas to express the unification of Muslims in terms of comprehension and appreciation. Undeniably, he has strived to establish Islam to the society by recognizing the Qur'an and Sunna as the basis of reformation. Therefore, this study attempts to analyse the intellectuality of alDihlawi as a famous hadith scholar and his contribution towards the appreciation of Sunna of the prophet. By applying content analysis method as the study design by focusing on his great work, Hujjat al-Baligha, the study found that the transformation carried out by al-Dihlawi then he was considered a moderate figure who tried to balance between demands worldly and hereafter goals to the community. His efforts toward the unity of umma were considered positively when succeed to quell internal dissent and ideology differences between the fighism and Sufism, and also between the rationalists (ahl al-Ra'y) and the traditionalists (ahl al-Hadith).
\end{abstract}

Keywords: Hadith; Al-Dihlawi; Intellectual; Hujjat al-Baligha, Sufism

\section{Shah Wali Allah Al-Dihlawi (1702-1762): A Biographical Highlight}

Shah Wali Allah was born on the $4^{\text {th }}$ of Shawwal, 1114/1702 in Pulth, in district Muzaffargarh, Delhi, India, (Jalbani, 1967). He has been dubbed as the Qutb al-Din which means religious center, while the word 'Shah' placed in front of his name comes from the Persian word which means king, and this title is only awarded to scholars and Sheikh Sufi (AlDihlawi: 2005: 12-13). He is also known as the Wali Allah as his profound understanding of the religion and from the point of use of this word is usually given to Sufi religious leaders and have miracles. His descendants came from Umar alKhattab the second Caliph of Islam. The word of al-Dihlawi is derived from the word New Delhi, which is the name of his hometown (Mahfudz, 2010).

al-Dihlawi is an important Muslim reformer in India. After studying in Delhi, al-Dihlawi spent some time in mecca, which was an important meeting place for Muslims from all corners of the world. When he returned to India, he called for the reform of a number of areas of Islamic belief and practice, suggesting that of the traditional four sources of Islamic law only two, the Quran and the hadith had ongoing validity, and that these needed creative interpretation (ijtihad) in order to make their message applicable in the Indian context. He therefore translated the Quran into Persian, the cultured language of Indian Muslims, and his sons translated it into Urdu. He also suggested that the hadith needed careful review, in order to clarify which sections were unreliable, this work thus serving as an early example of hadith criticism. And he also argued that the different schools of sharia law were no longer valid, and that was needed was a return to the situation before their emergence, so that there could be one school for all Muslims (Goddard, 2010). 